\title{
АНАЛІЗ ІНФОРМАТИВНОСТІ СИРОВАТКОВОЇ КОНЦЕНТРАЦІЇ ФЕРИТИНУ У ВИЗНАЧЕННІ ПРОГНОЗУ ПЕРЕБІГУ ТА ВИХОДУ ГОСТРОГО ПЕРІОДУ СПОНТАННОГО СУПРАТЕНТОРІАЛЬНОГО ВНУТРІШНЬОМОЗКОВОГО КРОВОВИЛИВУ
}

\author{
๑А. А. Кузнєцов
}

\section{Запорізький державний медичний університет}

РЕзюМЕ. Мета роботи - оцінити інформативність сироваткової концентрації феритину у визначенні індивідуального ризику раннього клініко-неврологічного погіршення та прогнозуванні виходу гострого періоду спонтанного супратенторіального внутрішньомозкового крововиливу (ССВМК) на тлі консервативної терапії.

Матеріал і методи. Проведено проспективне когортне порівняльне дослідження 88 пацієнтів у гострому періоді ССВМК на тлі консервативної терапії. Оцінку рівня неврологічного дефіциту здійснювали за шкалою коми Full Outline of Unresponsiveness та National Institute of Health Stroke Scale (NIHSS). Візуалізацію церебральних структур здійснювали методом комп'ютерної томографії. Впродовж 24 годин з моменту госпіталізації визначали вміст феритину та заліза в сироватці крові, загальну залізозв'язувальну здатність сироватки із наступним розрахунком коефіцієнта сатурації трансферину. Комбінованими клінічними кінцевими точками були раннє клініко-неврологічне погіршення (РКНП) та несприятливий вихід гострого періоду ССВМК у вигляді значення 4-6 балів за модифікованою шкалою Ренкіна на 21 добу захворювання. Статистичну обробку результатів здійснювали інструментами логістичного регресійного аналізу, ROC-аналізу, кореляційного аналізу.

Результати. Пацієнти з несприятливими варіантами перебігу та виходу гострого періоду ССВМК мали вищу сироваткову концентрацію феритину в першу добу з моменту госпіталізації, при цьому даний показник прямо корелював із тяжкістю ураження церебральних структур. Установлено, що оцінка вмісту феритину в сироватці крові разом із нейровізуалізаційними показниками (вираженість латеральної дислокації серединних структур мозку, обсяг вторинного внутрішньошлуночкового крововиливу) у складі розробленої мультипредикторної логіс-

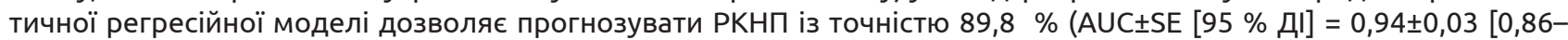
0,98], p<0,0001). Також розроблено високочутливу мультипредикторну логістичну регресійну модель, яка інтегрує прогностичну цінність сироваткової концентрації феритину з інформативністю клініко-нейровізуалізаційних показників (сумарний бал за NIHSS, обсяг вторинного внутрішньошлуночкового крововиливу) і дозволяє визначати індивідуальний ризик несприятливого виходу гострого періоду ССВМК на тлі консервативної терапії з точністю $87,5 \%$ (AUC \pm SE $[95 \%$ Дl] = 0,95 $\pm 0,02[0,89-0,99], p<0,0001)$.

Висновки. Вміст феритину в сироватці крові хворих на спонтанний супратенторіальний внутрішньомозковий крововилив $\epsilon$ інформативним додатковим показником для верифікації короткострокового прогнозу на тлі консервативної терапії.

КЛючОВІ СЛОВА: внутрішньомозковий крововилив; феритин; прогноз.

Вступ. Мозковий геморагічний інсульт (МГІ) найбільш руйнівний тип гострих порушень мозкового кровообігу, який відрізняється надзвичайно високими показниками смертності та інвалідизації населення у більшості країн світу, при цьому в останні роки зафіксовано стійкий тренд до неухильного збільшення захворюваності на МГІ у осіб молодого та середнього віку [1]. Незважаючи на суттєві досягнення нейронаук, проблема своєчасного вибору оптимальної лікувальної тактики у хворих на спонтанний супратенторіальний внутрішньомозковий крововилив (ССВМК), на жаль, залишається далекою від вирішення [2]. Найперспективнішим заходом у даному напрямі $\epsilon$ розробка інформативних критеріїв якомога ранішої верифікації індивідуального прогнозу в якості складової підґрунтя для прийняття оптимальних лікувально-тактичних рішень [3].

У рутинній клінічній практиці визначення прогнозу у хворих на ССВМК головним чином базується на результатах клініко-нейровізуалізаційної оцінки тяжкості ураження церебральних структур [4]. Необхідність підвищення точності клініко-нейровізуалізаційної верифікації прогнозу обґрунтовує доцільність подальшого пошуку інформативних параметрів, які асоційовані з виходом гострого періоду захворювання і можуть надати додаткову (цінну у прогностичному аспекті) інформацію. 3 огляду на вищенаведене вельми перспективним вбачається дослідження прогностичної цінності гуморальних маркерів, особливо тих із них, які дозволяють об'єктивізувати патогенетичні механізми реалізації гострої церебральної геморагії.

Як відомо, провідною складовою механізмів вторинного ушкодження нервової тканини, що індуковані внутрішньомозковим крововиливом, $\epsilon$ прозапальна активація $[5,6]$. Одним з найінформативніших маркерів прозапальної активації $\epsilon$ феритин [7]. Згідно з даними нещодавно проведеного мета-аналізу, доведеним $€$ взаємозв'язок вмісту феритину в сироватці крові з наслідком внутрішньомозкового крововиливу [8]. Разом із тим, відсутні роботи щодо оцінки інформативності сиро- 
Огляди літератури, оригінальні дослідження, погляд на проблему, випадок з практики, короткі повідомлення

ваткової концентрації феритину у визначенні індивідуального ризику раннього клініко-неврологічного погіршення у хворих на ССВМК. Також доцільним є дослідження інформативності вмісту феритину в сироватці крові у разі застосування разом із клініко-нейровізуалізаційними показниками для прогнозування виходу гострого періоду ССВМК.

Мета - оцінити інформативність сироваткової концентрації феритину у визначенні індивідуального ризику раннього клініко-неврологічного погіршення та прогнозуванні виходу гострого періоду спонтанного супратенторіального внутрішньомозкового крововиливу на тлі консервативної терапії.

Матеріал і методи дослідження. Для досягнення поставленої мети було проведено проспективне когортне порівняльне дослідження 88 пацієнтів (47 чоловіків та 41 жінка, медіана віку - 65 [59-74] років) у гострому періоді ССВМК. Усі пацієнти були госпіталізовані у відділення гострих порушень мозкового кровообігу Комунального некомерційного підприємства «Міська лікарня № 6» Запорізької міської ради у термін до 24 годин від дебюту захворювання. Обов'язковою була підписана інформована згода на участь пацієнта у дослідженні.

Рівень неврологічного дефіциту визначали під час надходження до стаціонару та в динаміці перебігу захворювання за допомогою шкал коми Full Outline of UnResponsiveness (FOUR) та National Institute of Health Stroke Scale (NIHSS). Візуалізацію церебральних структур здійснювали методом комп'ютерної томографії в 1-шу добу захворювання з використанням апаратів Siemens Somatom Spirit (Федеративна Республіка Німеччина) або Toshiba Asteion (Японія), при цьому визначали такі показники: обсяг внутрішньомозкового крововиливу (ОВМК) - за формулою еліпсоїда, вираженість латеральної дислокації (ЛД) серединних структур мозку - як середнє від зсуву прозорої перетинки та епіфіза, обсяг вторинного внутрішньошлуночкового крововиливу (ОВВШК) - за такою формулою: ОВВШК=е^(IVHS/5), де IVHS - значення сумарного бала за шкалою оцінки тяжкості OВВШК - Intraventricular Hemorrhage Scale [4]. 3aгальний обсяг інтракраніальної геморагії (ЗОІКГ) розраховували шляхом сумування ОВМК та ОВВШК.

Протягом 24 годин з моменту госпіталізації у всіх пацієнтів здійснювали забір лабораторних зразків крові натще. Вміст феритину в сироватці крові визначали методом імуноферментного аналізу з використанням набору реактивів «Ferritin AccuBind VAST ELISA Kit» (Product Code: 2825-300, Monobind Inc., USA) на імуноферментному комплексі «ImmunoChem-2100» (США) в клініко-діагнос- тичній лабораторії Університетської клініки Запорізького державного медичного університету. Для діагностики латентного дефіциту заліза, який чинить незалежний вплив на вміст феритину в сироватці крові і тим самим здатний потенційно знизити його інформативність як маркера прозапальної активації, у всіх пацієнтів визначали сироватковий рівень заліза та загальну залізозв'язувальну здатність сироватки. Зазначені дослідження проводили на біохімічному автоматичному аналізаторі «Accent 200» (Cormay, Польща). 3 дослідження виключали пацієнтів із коефіцієнтом сатурації трансферину <15 \% та/а6о рівнем феритину, що був нижче референтних значень (<16 нг/мл для чоловіків, <10 нг/мл для жінок).

Усі пацієнти були оглянуті нейрохірургом. В якості оптимальної лікувальної тактики була обрана консервативна терапія, яку пацієнти отримували згідно з уніфікованим клінічним протоколом надання спеціалізованої допомоги хворим на спонтанний внутрішньомозковий крововилив, затвердженим наказом Міністерства охорони здоров'я України № 275 від 17.04.2014 року.

Реєстрували такі комбіновані кінцеві клінічні точки: 1) раннє клініко-неврологічне погіршення (настання протягом 48 годин з моменту госпіталізації однієї або декількох з наведених нижче подій: збільшення вираженості загальномозкового синдрому у вигляді зниження сумарного бала за шкалою коми FOUR $\geq 2$; поглиблення неврологічного дефіциту у вигляді збільшення сумарного бала за NIHSS $\geq 4$; летальний вихід); 2) несприятливий вихід гострого періоду ССВМК (значення 4-6 балів за модифікованою шкалою Ренкіна (modified Rankin Scale - mRS) на 21 добу захворювання) - інтегрує випадки летального виходу протягом гострого періоду захворювання, а також глибоку інвалідизацію у вигляді значення 4-5 балів за $\mathrm{mRS}$ на 21 добу ССВМК.

3 дослідження виключали пацієнтів, які відповідали наступним критеріям: 1) гострі порушення мозкового кровообігу в анамнезі; 2) нейровізуалізаційні критерії гострого мультифокального ушкодження церебральних структур; 3) наявність аневризми чи артеріо-венозної мальформації церебральних судин, що підтверджена за даними нейровізуалізаційного дослідження та/чи аутопсії; 4) вторинний внутрішньомозковий крововилив, що обумовлений іншими захворюваннями (ішемічний інсульт, пухлина головного мозку) та/чи прийомом антикоагулянтів; 5) відмова від проведення рекомендованого нейрохірургом оперативного втручання; 6) декомпенсована соматична патологія; 7) анемія будь-якого ґенезу (в анамнезі та/ чи під час госпіталізації); 8) підтверджений латентний дефіцит заліза; 9) злоякісні новоутворення; 
Огляди літератури, оригінальні дослідження, погляд на проблему, випадок з практики, короткі повідомлення

10) екстрацеребральний ґенез летального виходу за даними аутопсії.

Статистичну обробку отриманих результатів проводили за допомогою програм Statistica 13.0 (Statsoft Inc., USA, серійний номер JPZ804I382130ARCN10J) та MedCalc (version 18.2.1). Оскільки розподіл більшості досліджуваних показників відрізнявся від нормального за критерієм Шапіро - Уїлка, дескриптивна статистика була подана у вигляді медіани та міжквартильного інтервалу. Міжгрупові відмінності оцінювали за критерієм Манна - Уїтні. Також використовували кореляційний аналіз, логістичний регресійний аналіз, ROC-аналіз, розраховували показники відносного ризику (ВР) разом з 95 \% довірчим інтервалом (ДІ). Статистично значущими вважали результати з рівнем $\mathrm{p}<0,05$.

Результати й обговорення. Групові значення досліджуваних показників у загальній когорті пацієнтів на момент їх включення в дослідження були представлені так: сумарний бал за шкалою коми FOUR - 15 [14-16], сумарний бал за NIHSS 14 [10-17], ОВМК - 12,3 [5,7-24,7] мл, лД-2,0 [0,04,0] мм, ОВВШК - 6,0 [0,0-16,4] мл, ЗОІКГ - 21,6 [10,5-46,9] мл, вміст феритину в сироватці крові $80,4[45,6-148,2]$ нг/мл $(70,4[43,0-131,8]$ нг/мл та $95,4[61,5-176,5]$ нг/мл у осіб чоловічої та жіночої статі відповідно, $\mathrm{p}=0,2329)$.

Клініко-неврологічне погіршення протягом 48 годин з моменту госпіталізації було зафіксовано у 18 (20,5 \%) осіб. Установлено, що пацієнти, у яких перебіг гострого періоду ССВМК супроводжувався розвитком РКНП, у 1-шу добу відрізнялися тяжчим ушкодженням церебральних структур за даними нейровізуалізаційного дослідження: OBMК - 45,7 [13,6-70,8] мл, ЛД - 4,5 [2,5-6,5] мм, ОВВШК - 30,0 [11,8-41,0] мл, ЗОІКГ - 73,3 [51,5101,2] мл, що перевищувало значення медіани аналогічних показників у когорті пацієнтів без РКНП відповідно в 4, 1 ( $p=0,0005), 3,0$ ( $p=0,0002), 9,1$ $(p=0,0003)$ та 4,6 раза $(<0,0001)$ і обумовлювало загалом нижчий сумарний бал за шкалою коми FOUR (14 [14-15] проти 16 [14-16], p=0,0040). Також виявлено міжгрупові відмінності вмісту феритину в сироватці крові - медіана даного показника в групі пацієнтів з РКНП була вищою в 3,6 раза $(243,2$ [134,4-319,0] нг/мл проти 67,3 [39,7-106,7] нг/мл, $\mathrm{p}<0,0001)$.

За даними множинного логістичного регресійного аналізу були ідентифіковані наступні показники, які незалежно асоційовані з ризиком РКНП у пацієнтів із ССВМК: вираженість ЛД (ВШ $[95 \%$ ДІ] = 1,63 [1,12-2,37], p=0,0107), ОВВШК (ВШ $[95 \%$ ДІ $]=1,07[1,02-1,12], p=0,0038)$ та сироваткова концентрація феритину (ВШ $95 \%$ ДІ $]=$ $1,01[1,00-1,02], p=0,0015)$. Для прогнозування
РКНП у хворих на ССВМК зазначені показники було інтегровано у мультипредикторну математичну модель у вигляді рівняння бінарної логістичної регресії, яке має наступний вигляд:

$\beta 1=-5,80+0,49 \times$ Pred 1+0,07×Pred2+0,01 $\times$ Pred3, де

$-5,80$ - вільний член рівняння $(\beta 0)$;

Pred1 - вираженість латеральної дислокації серединних структур мозку (мм);

Pred2 - обсяг вторинного внутрішньошлуночкового крововиливу (мл);

Pred3 - сироваткова концентрація феритину (нг/мл).

На підставі ROC-аналізу визначено порогове значення $\beta 1$ (>-2,02), яке $\epsilon$ інтегральним предиктором клініко-неврологічного погіршення у хворих на ССВМК протягом 48 годин з моменту госпіталізації (Se=94,4%, Sp=84,3%). Оцінку інформативності та якості розробленої математичної моделі здійснено за такими показниками: рівень значущості тесту Хосмера-Лемешова $p=0,5828$; точність прогнозування (питома вага істинно позитивних та істинно негативних результатів) -

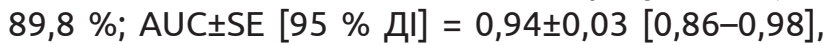
p<0,0001 (рис. 1).

Раннє клініко-неврологічне погіршення в групі пацієнтів зі значенням $\beta 1>-2,02(n=28)$ було зафіксовано в 60,7 \% випадків проти лише 1,7 \% в когорті хворих зі значенням $\beta 1<-2,02$ (BP [95 \% ДІ] = 36,4 [5,1-260,3], p=0,0003).

На підставі порівняльного аналізу показників AUC встановлено, що розроблена модель множинної логістичної регресії $\epsilon$ більш інформативною у визначенні індивідуального ризику раннього клініко-неврологічного погіршення у хворих на ССВМК, ніж окремі предиктори, що входять до її складу (рис. 2).

Комбінована кінцева клінічна точка (несприятливий вихід гострого періоду (CВМК) у вигляді значення 4-6 балів за mRS на 21 добу захворювання була зареєстрована у 48 (54,5 \%) пацієнтів. Структура зазначеної кінцевої точки була представлена наступним чином: летальний вихід протягом гострого періоду ССВМК - 13 (27,1\%) випадків (14,8 \% від загальної кількості пацієнтів), глибока інвалідизація у вигляді значення 4-5 балів на 21 добу захворювання (несприятливий функціональний вихід гострого періоду (СВМК) - 35 (72,9 \%) осіб (39,8 \% від загальної когорти хворих). Установлено, що пацієнти, в яких гострий період ССВМК мав несприятливий вихід, в 1-шу добу відрізнялися тяжчим ушкодженням церебральних структур за нижченаведеними показниками: сумарний бал за шкалою коми FOUR (14 [14-16] проти 16 [15-16], p=0,0004), NIHSS (17 [14-19] проти 10 [8-13], $p<0,0001)$, OBMK $(22,5[11,2-44,4]$ мл 
Огляди літератури, оригінальні дослідження, погляд на проблему, випадок з практики, короткі повідомлення проти 7,6 [4,4-12,6] мл, р<0,0001), ЛД (3,5 [1,5-4,5] мм 30,0] мл проти 0,0 [0,0-2,9] мл, p<0,0001), 30ІКГ (40,2 проти 0,0 [0,0-1,5] мм, p<0,0001), ОВВШК $(13,5[6,0-\quad[25,7-66,8]$ мл проти 10,5 [4,6-14,7] мл, p<0,0001).

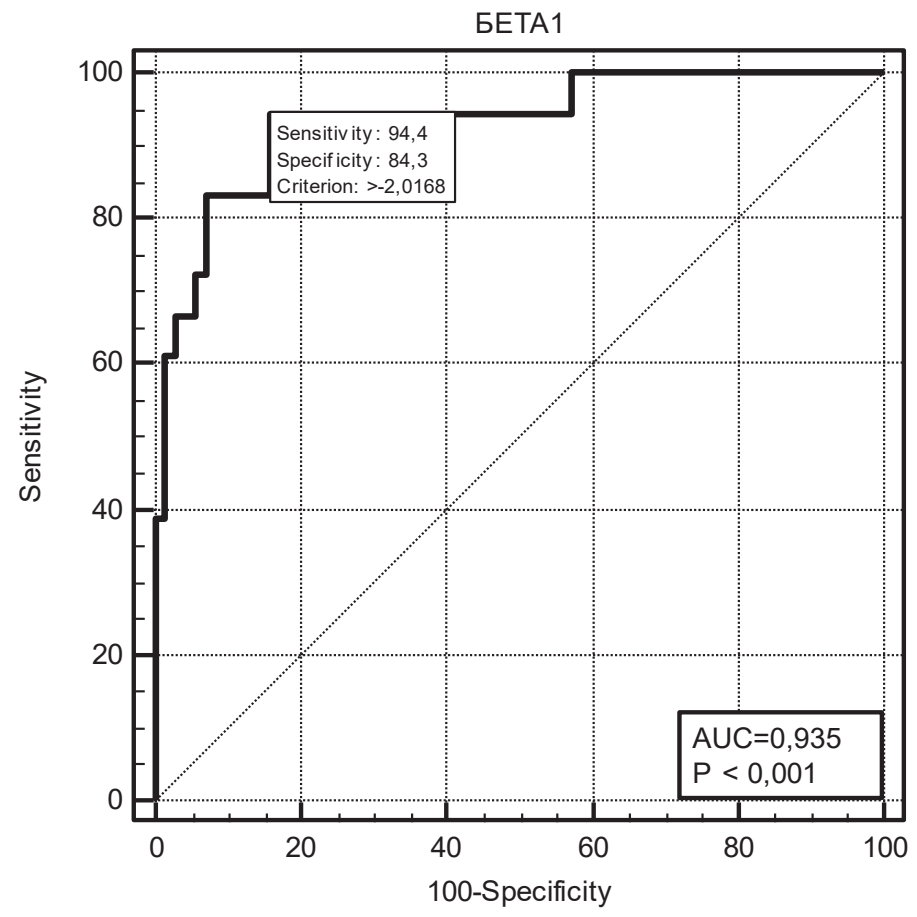

Pис. 1. ROC-крива розробленої мультипредикторної математичної моделі для визначення індивідуального ризику раннього клініко-неврологічного погіршення у хворих на ССВМК, яка враховує ініціальні нейровізуалізаційні показники (вираженість латеральної дислокації серединних структур мозку, обсяг вторинного внутрішньошлуночкового крововиливу) та вміст феритину в сироватці крові.

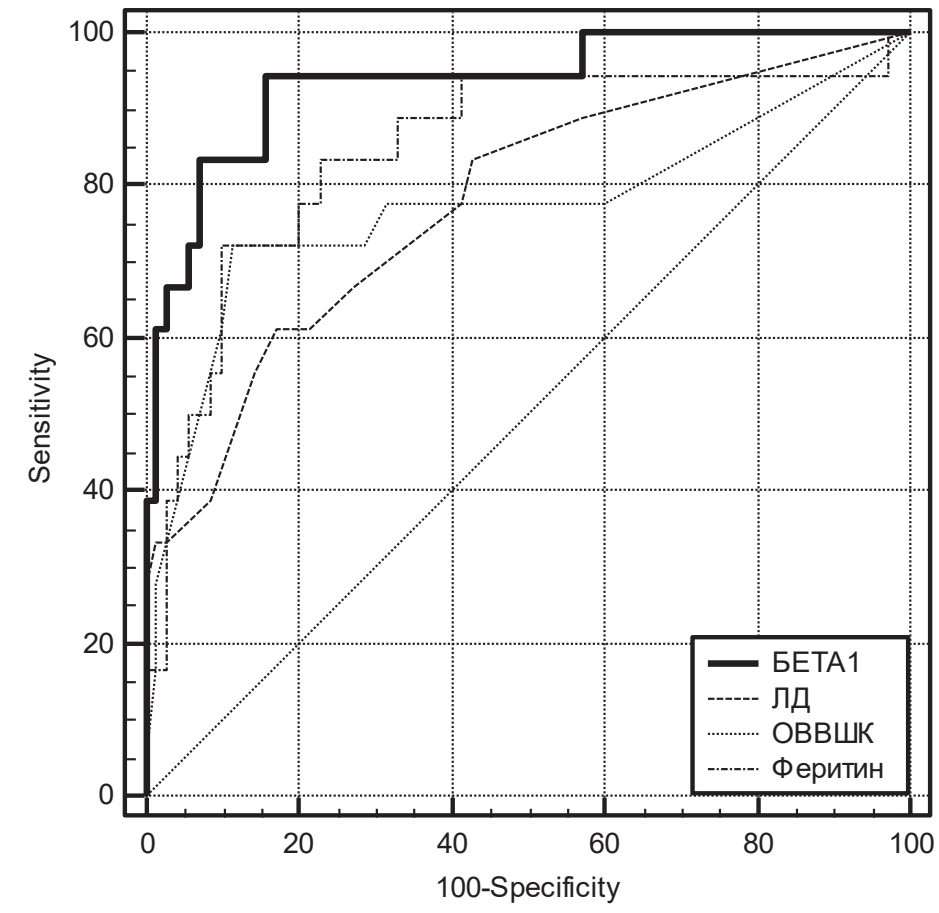

Рис. 2. Порівняльний аналіз інформативності розробленої моделі множинної логістичної регресії та окремих предикторів, які входять до її складу, у визначенні індивідуального ризику раннього клініко-неврологічного погіршення у пацієнтів із ССВМК на тлі консервативної терапії. 
Огляди літератури, оригінальні дослідження, погляд на проблему, випадок з практики, короткі повідомлення

Медіана сироваткової концентрації феритину в зазначеній вище когорті хворих була вищою в 2,1 раза $(120,4[87,1-250,8]$ нг/мл проти 57,2 [33,072,9] нг/мл, р<0,0001).

За даними множинного логістичного регресійного аналізу встановлено, що з ризиком несприятливого виходу гострого періоду ССВМК незалежно асоційовані сумарний бал за NIHSS (ВШ $(95 \%$ ДI) $=1,70(1,28-2,25), p=0,0002)$, ОВВШК (ВШ $(95 \%$ ДI) $=1,21(1,07-1,35), p=0,0016)$ та сироваткова концентрація феритину (ВШ (95\% ДІ) $=1,02$ $(1,00-1,03), p=0,0059)$. Для прогнозування виходу гострого періоду ССВМК зазначені показники були інтегровані у мультипредикторну математичну модель у вигляді рівняння бінарної логістичної регресії, яке має наступний вигляд:

$\beta 2=-10,01+0,53 \times$ Pred $1+0,19 \times$ Pred $2+0,02 \times$ Pred3, де
$-10,01$ - вільний член рівняння ( $(\beta 0) ;$

Pred1 - сумарний бал за NIHSS;

Pred2 - обсяг вторинного внутрішньошлуночкового крововиливу (мл);

Pred3 - сироваткова концентрація феритину (нг/Мл).

На підставі ROC-аналізу визначено порогове значення $\beta 2(>-0,08)$, яке виступає інтегральним предиктором несприятливого виходу гострого періоду ССВМК у вигляді значення 4-6 балів за $\mathrm{mRS}$ на 21 добу захворювання ( $\mathrm{Se}=95,8$ \%, $\mathrm{Sp}=82,5 \%$ ). Аналіз інформативності та якості розробленої математичної моделі проведено за нижченаведеними показниками: рівень значущості тесту Хосмера - Лемешова $\mathrm{p}=0,7675$; точність прогнозування (питома вага істинно позитивних та істинно негативних результатів) - 87,5 \%; AUC \pm SE [95 \% ДI] = $0,95 \pm 0,02[0,89-0,99], p<0,0001$ (рис. 3).

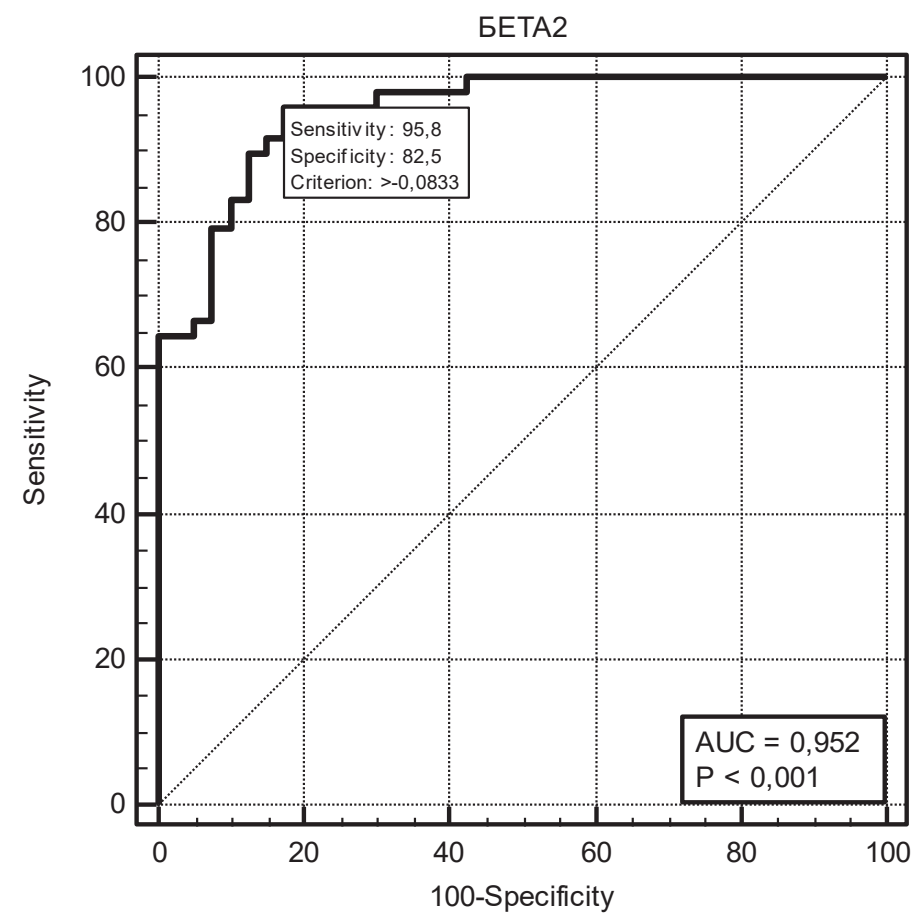

Рис. 3. ROC-крива розробленої мультипредикторної математичної моделі для прогнозування виходу гострого періоду CCBMK на підставі поєднаного використання сумарного балу за NIHSS, обсягу вторинного внутрішньошлуночкового крововиливу та сироваткової концентрації феритину протягом 24 годин з моменту госпіталізації.

Несприятливий вихід (значення 4-5 балів за mRS на 21 добу CCBMK) у групі пацієнтів зі значенням $\beta 2>-0,08$ (n=53) було зафіксовано в 86,8 \% випадків проти 5,7\% в когорті хворих зі значенням $\beta 2<-0,08$ (ВР [95\% ДІ $=15,2[3,9-58,6], p=0,0001)$.

На підставі порівняльного аналізу показників AUC встановлено, що розроблена модель множинної логістичної регресії $\epsilon$ більш інформативною у визначенні індивідуального ризику несприятливого виходу гострого періоду ССВМК, ніж окремі предиктори, що входять доїї складу (рис. 4).
Пацієнти, у яких гострий період ССВМК закінчився летальним результатом, в 1-шу добу також відрізнялися більш високим вмістом феритину в сироватці крові $(200,3[124,8-327,1]$ нг/мл проти 74,2 [44,8-120,4] нг/мл в групі хворих, що вижили, $\mathrm{p}=0,0014)$. Разом із тим, результати множинного логістичного регресійного аналізу не виявили незалежного зв'язку вмісту феритину в сироватці крові з ризиком летального виходу гострого періоду ССВМК у обстеженої когорти хворих. 
Огляди літератури, оригінальні дослідження, погляд на проблему, випадок з практики, короткі повідомлення

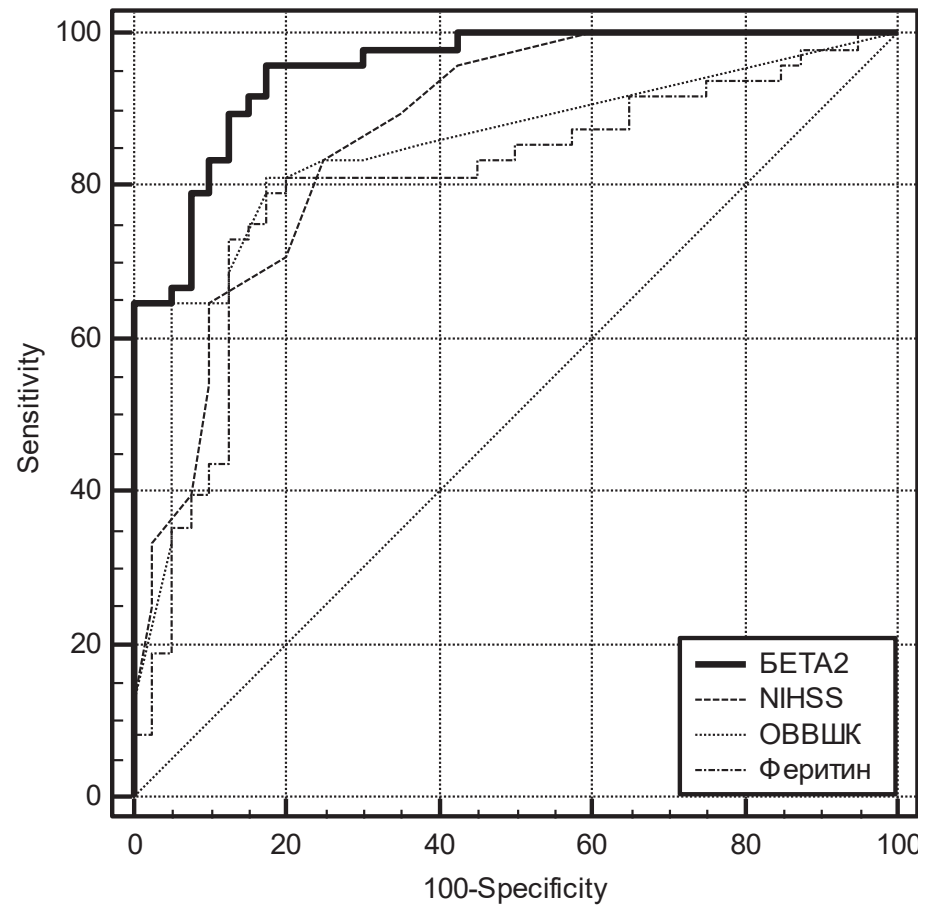

Рис. 4. Порівняльний аналіз інформативності розробленої моделі множинної логістичної регресії та окремих предикторів, які входять до її складу, у визначенні індивідуального ризику раннього клініко-неврологічного погіршення у пацієнтів з ССВМК на тлі консервативної терапії.

3 метою інтерпретації наявності сироваткової концентрації феритину в спектрі параметрів, які асоційовані з перебігом та виходом гострого періоду ССВМК, проведено аналіз вмісту феритину в сироватці крові залежно від тяжкості ураження церебральних структур. Так, рівень сироваткової концентрації феритину в групі пацієнтів з ОВМК $>30$ мл $(n=20)$ був вищим в 2,9 раза $(205,3[106,4-$ 291,5] нг/мл проти 71,4 [43,3-112,0] нг/мл у групі пацієнтів з ОВМК $\leq 30$ мл, $p=0,0007)$, в когорті хворих з ОВВШК >15 мл (n=23) - вище в 2,4 раза $(160,1$ [88,3-272,0] нг/мл проти 66,4 [39,1-118,2] нг/мл у хворих з ОВВШК $\leq 15$ мл, $\mathrm{p}=0,0002)$, в групі пацієнтів з 3ОІКГ >40 мл (n=25) - вище в 2,9 раза $(192,1$ [96,5-290,4] нг/мл проти 67,1 [41,9-105,9] нг/мл у хворих з 3ОІКГ $\leq 40$ мл, p=0,0001). На підставі кореляційного аналізу з розрахунком коефіцієнта рангової кореляції Спірмена встановлено, що вміст феритину в сироватці крові пацієнтів із ССВМК асоційований з ОВМК $(R=0,41, p<0,01)$, ОВВШК $(R=0,30$, $p<0,01)$ та 3ОІКГ $(R=0,49, p<0,01)$. Отримані дані можна пояснити тим, що тяжче ушкодження церебральних структур ініціює більш виражену прозапальну активацію, одним із діагностичних маркерів якої $є$ сироваткова концентрація феритину.

Таким чином, пацієнти, у яких у гострому періоді захворювання були зареєстровані комбіновані клінічні кінцеві точки (РКНП, несприятливий вихід у вигляді значення 4-6 балів за mRS на 21-шу добу
(CВMК) достовірно відрізнялися більш високим ініціальним вмістом феритину в сироватці крові, що узгоджується з даними інших дослідників. Так, у роботі S. R. Rajendran et al. (2020) було продемонстровано, що сироваткова концентрація феритину прямо корелює з ОВМК, при цьому більш високий ініціальний вміст феритину в сироватці крові пацієнтів з внутрішньомозковим крововиливом асоційований з гіршим виходом на 30-ту добу захворювання [9]. У дослідженнях G. Yang et al. (2016), A. Garton et al. (2017) було виявлено, що пацієнти, у яких вихід внутрішньомозкового крововиливу на 90-ту добу оцінювався як несприятливий, в гострому періоді захворювання також відрізнялися більш високою сироватковою концентрацією феритину $[10,11]$.

Ініціальний вміст феритину в сироватці крові пацієнтів з ССВМК за результатами множинного логістичного регресійного аналізу було включено до складу високочутливих мультипредикторних моделей для прогнозування РКНП (разом ОВВШК та вираженістю ЛД) та несприятливого виходу гострого періоду ССВМК (разом з ОВВШК та сумарним балом за NIHSS). Як показали результати порівняльного ROC-аналізу, зазначений підхід сприяв підвищенню точності прогнозування за рахунок інтеграції інформативності сироваткової концентрації феритину та інших досліджуваних параметрів, адже розроблені моделі мно- 
Огляди літератури, оригінальні дослідження, погляд на проблему, випадок з практики, короткі повідомлення жинної логістичної регресії відрізнялися більш високим показником AUC, порівняно з окремими предикторами, що увійшли до їх складу. Визначено порогові значення показників $\beta 1$ та $\beta 2$ із оптимальним співвідношенням чутливості та специфічності, які виступають інтегральними предикторами РКНП та несприятливого виходу гострого періоду ССВМК. Результати аналізу якості розроблених прогностичних моделей (точність прогнозування >85 \%, AUC >0,90) обґрунтовують доцільність їх застосування в рутинній клінічній практиці для якомога раннього (протягом 24 годин 3 моменту госпіталізації) виявлення пацієнтів із критично високими ризиками РКНП та несприятливого виходу гострого періоду ССВМК на тлі консервативної терапії в якості складової підґрунтя для своєчасного прийняття оптимальних лікувально-тактичних рішень.

Висновки. 1. Сироваткова концентрація феритину у хворих на спонтанний супратенторіальний внутрішньомозковий крововилив корелює 3 тяжкістю ураження церебральних структур і $\epsilon$ інформативним додатковим показником для верифікації короткострокового прогнозу на тлі консервативної терапії.

2. Оцінка вмісту феритину в сироватці крові разом з нейровізуалізаційними показниками (вираженість латеральної дислокації серединних структур мозку, обсяг вторинного внутрішньошлуночкового крововиливу) у складі розробленої мультипредикторної логістичної регресійної

моделі дозволяє визначати індивідуальний ризик раннього клініко-неврологічного погіршення на тлі консервативної терапії з точністю 89,8 \%

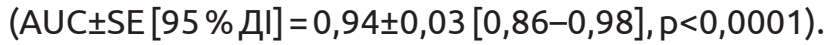

3. Розроблено високочутливу мультипредикторну логістичну регресійну модель, яка інтегрує прогностичну цінність сироваткової концентрації феритину з інформативністю клініко-нейровізуалізаційних показників (сумарний бал за NIHSS, обсяг вторинного внутрішньошлуночкового крововиливу) і дозволяє визначати індивідуальний ризик несприятливого виходу гострого періоду CCBMК на тлі консервативної терапії з точністю

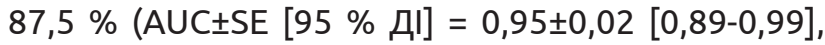
$\mathrm{p}<0,0001)$.

Перспективи подальших досліджень полягають в аналізі інформативності інтегральної оцінки показників метаболізму заліза у визначенні короткострокового прогнозу перебігу та виходу гострого періоду ССВМК.

Фінансування. Дослідження виконано в рамках НДР кафедри нервових хвороб Запорізького державного медичного університету «Оптимізація діагностичних та лікувально-реабілітаційних заходів у хворих з гострими і хронічними порушеннями мозкового кровообігу», № держ. реєстрації 0113 U000798 (2013-2017) та «Удосконалення діагностики, лікування та прогнозування гострих та хронічних форм порушень мозкового кровообігу на різних етапах захворювання", № держ. реєстрації $0118 U 007145$ (2018-2023).

\section{ЛІТЕРАТУРА}

1. Адаптована клінічна настанова «Геморагічний інсульт. Спонтанний внутрішньомозковий крововилив» - Режим доступу: httр://mtd.dec.gov.ua/images/ dodatki/2014_275_Gl/2014_275_AKN_vnytrkrov_Gl.pdf.

2. Gregson B. A. Surgical Decision Making in Brain Hemorrhage / B. A. Gregson, P. Mitchell, A. D. Mendelow // Stroke. - 2019. - Vol. 50 (5). - P. 1108-1115.

3. Tilling E. J. Do Clinicians Overestimate the Severity of Intracerebral Hemorrhage? / E. J. Tilling, S. El Tawil, K. W. Muir // Stroke. - 2019. - Vol. 50(2). - P. 344-348.

4. Kuznietsov A. A. Comparative analysis of predictive significance of neuroimaging parameters in patients with spontaneous supratentorial intracerebral hemorrhage / A. A. Kuznietsov // Zaporozhye Medical Journal. 2018. - Vol. 20 (4). - P. 543-547.

5. Role and mechanisms of cytokines in the secondary brain injury after intracerebral hemorrhage / H. Zhu, Z. Wang, J. Yu [et al.] // Progress in neurobiology. - 2019. Vol. 178. - P. 101610.

6. Pathophysiological Mechanisms and Potential Therapeutic Targets in Intracerebral Hemorrhage / Z. Shao, S. Tu, A. Shao // Frontiers in pharmacology. - 2019. Vol. 10. - P. 1079.

7. Kell D. B. Serum ferritin is an important inflammatory disease marker, as it is mainly a leakage product from damaged cells / D. B. Kell, E. Pretorius // Metallomics: integrated biometal science. - 2014. - Vol. 6(4). - P. 748-773.

8. Association Between Baseline Serum Ferritin and Short-term Outcome of Intracerebral Hemorrhage: A MetaAnalysis / M. Zhang, W. Li, T. Wang [et al.] // Journal of stroke and cerebrovascular diseases : the official journal of National Stroke Association. - 2019. - Vol. 28 (7). - P. 1799-1805.

9. Evaluation of Serum Ferritin as a Prognostic Marker in Acute Hemorrhagic Stroke / S. R. Rajendran, S. Periyasamy, M. T. Manjuladevi [et al.] // Journal of neurosciences in rural practice. - 2020. - Vol. 11 (1). - P. 72-77.

10. A combination of serum iron, ferritin and transferrin predicts outcome in patients with intracerebral hemorrhage / G. Yang, R. Hu, C. Zhang [et al.] // Scientific reports. - 2016. - Vol. 6. - P. 21970.

11. Biomarkers of Functional Outcome in Intracerebral Hemorrhage: Interplay between Clinical Metrics, CD163, and Ferritin / A. Garton, V. P. Gupta, B. R. Christophe [et al.] // Journal of stroke and cerebrovascular diseases : the official journal of National Stroke Association. 2017. - Vol. 26(8). - P. 1712-1720. 
Огляди літератури, оригінальні дослідження, погляд на проблему, випадок з практики, короткі повідомлення REFERENCES

1. (2014). Adaptovana klinichna nastanova «Hemorahichnyi insult. Spontannyi vnutrishnomozkovyi krovovylyv» Ministerstvo okhorony zdorovia Ukrainy [Adapted clinical guidance "Hemorrhagic stroke. Subarachnoid hemorrhage" Ministry of Health of Ukraine]. Retrieved from: http://mtd. dec.gov.ua/images/dodatki/2014_275_Gl/2014_275_AKN_ vnytrkrov_Gl.pdf

2. Gregson, B.A., Mitchell, P., \& Mendelow, A.D. (2019). Surgical Decision Making in Brain Hemorrhage. Stroke, 50 (5), 1108-1115. https://doi.org/10.1161/STROKEAHA. 118.022694

3. Tilling, E.J., El Tawil, S., \& Muir, K.W. (2019). Do Clinicians Overestimate the Severity of Intracerebral Hemorrhage? Stroke, 50 (2), 344-348. https://doi.org/10.1161/ STROKEAHA.118.022606

4. Kuznietsov, A.A. (2018). Comparative analysis of predictive significance of neuroimaging parameters in patients with spontaneous supratentorial intracerebral hemorrhage. Zaporozhye Medical Journal, 20 (4), 543-547. Retrieved from: https://doi.org/10.14739/2310-1210. 2018.4.137097

5. Zhu, H., Wang, Z., Yu, J., Yang, X., He, F., Liu, Z., Che, F., Chen, X., Ren, H., Hong, M., \& Wang, J. (2019). Role and mechanisms of cytokines in the secondary brain injury after intracerebral hemorrhage. Progress in neurobiology, 178, 101610. https://doi.org/10.1016/j.pneurobio.2019.03

6. Shao, Z., Tu, S., \& Shao, A. (2019). Pathophysiological Mechanisms and Potential Therapeutic Targets in Intracerebral Hemorrhage. Frontiers in pharmacology, 10,
1079. https://doi.org/10.3389/fphar.2019.01079.003

7. Kell, D.B., \& Pretorius, E. (2014). Serum ferritin is an important inflammatory disease marker, as it is mainly a leakage product from damaged cells. Metallomics: integrated biometal science, 6 (4), 748-773. https://doi.org/10.1039/ c3mt00347g

8. Zhang, M., Li, W., Wang, T., \& Zhang, Q. (2019). Association Between Baseline Serum Ferritin and Short-term Outcome of Intracerebral Hemorrhage: A Meta-Analysis. Journal of stroke and cerebrovascular diseases : the official journal of National Stroke Association, 28 (7), 1799-1805. https://doi.org/10.1016/j.jstrokecerebrovasdis.2019.03.037

9. Rajendran, S.R., Periyasamy, S., Manjuladevi, M.T., \& George, N. (2020). Evaluation of Serum Ferritin as a Prognostic Marker in Acute Hemorrhagic Stroke. Journal of neurosciences in rural practice, 11 (1), 72-77. https://doi. org/10.1055/s-0039-1700597

10. Yang, G., Hu, R., Zhang, C., Qian, C., Luo, Q.Q., Yung, W.H., Ke, Y., Feng, H., \& Qian, Z. M. (2016). A combination of serum iron, ferritin and transferrin predicts outcome in patients with intracerebral hemorrhage. Scientific reports, 6, 21970. https://doi.org/10.1038/srep21970

11. Garton, A., Gupta, V.P., Christophe, B.R., \& Connolly, E.S., Jr (2017). Biomarkers of Functional Outcome in Intracerebral Hemorrhage: Interplay between Clinical Metrics, CD163, and Ferritin. Journal of stroke and cerebrovascular diseases : the official journal of National Stroke Association, 26 (8), 1712-1720. https://doi.org/10.1016/j. jstrokecerebrovasdis.2017.03.035

\title{
АНАЛИЗ ИНФОРМАТИВНОСТИ СЫВОРОТОЧНОЙ КОНЦЕНТРАЦИИ ФЕРРИТИНА В ОПРЕДЕЛЕНИИ ПРОГНОЗА ТЕЧЕНИЯ И ИСХОДА ОСТРОГО ПЕРИОДА СПОНТАННОГО СУПРАТЕНТОРИАЛЬНОГО ВНУТРИМОЗГОВОГО КРОВОИЗЛИЯНИЯ
}

\author{
๑А. А. Кузнецов
}

\section{Запорожский государственный медицинский университет}

РЕзЮМЕ. Цель - оценить информативность сывороточной концентрации ферритина в определении индивидуального риска раннего клинико-неврологического ухудшения и прогнозировании исхода острого периода спонтанного супратенториального внутримозгового кровоизлияния (ССВМК) на фоне консервативной терапии.

Материал и методы. Проведено проспективное когортное сравнительное исследование 88 пациентов в остром периоде ССВМК на фоне консервативной терапии. Оценку уровня неврологического дефицита осуществляли по шкале комы Full Outline of Unresponsiveness и National Institute of Health Stroke Scale (NIHSS). Визуализацию церебральных структур осуществляли методом компьютерной томографии. В течение 24 часов с момента госпитализации определяли содержание ферритина и железа в сыворотке крови, общую железосвязывающую способность сыворотки с последующим расчетом коэффициента сатурации трансферрина. Комбинированными клиническими конечными точками выступали раннее клинико-неврологическое ухудшение (РКНУ) и неблагоприятный исход острого периода ССВМК в форме значения 4-6 баллов по модифицированной шкале Рэнкина на 21 сутки заболевания. Статистическая обработка результатов осуществлялась инструментами логистического регрессионного анализа, ROC-анализа, корреляционного анализа.

Результаты. Пациенты с неблагоприятными вариантами течения и исхода острого периода ССВМК отличались более высоким содержанием ферритина в первые сутки с момента госпитализации, при этом данный показатель прямо коррелировал с тяжестью поражения церебральных структур. Установлено, что оценка содержания ферритина в сыворотке крови вместе с нейровизуализационными показателями (выраженность латеральной дислокации срединных структур мозга, объем вторичного внутрижелудочкового кровоизлияния) в составе разработанной мультипредикторной логистической регрессионной модели позволяет прогнозировать РКНУ с точ-

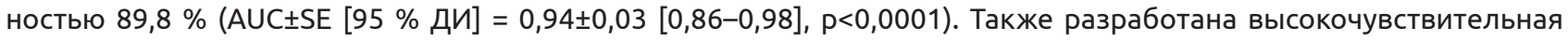


Огляди літератури, оригінальні дослідження, погляд на проблему, випадок з практики, короткі повідомлення мультипредикторная логистическая регрессионная модель, которая интегрирует прогностическую ценность сывороточной концентрации ферритина с информативностью клинико-нейровизуализационных показателей (суммарный балл по NIHSS, объем вторичного внутрижелудочкового кровоизлияния) и позволяет определять индивидуальный риск неблагоприятного исхода острого периода ССВМК на фоне консервативной терапии с точ-

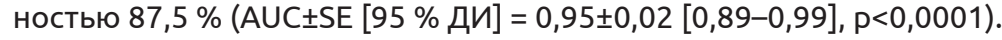

Выводы. Содержание ферритина в сыворотке крови больных спонтанным супратенториальным внутримозговым кровоизлиянием является информативным дополнительным показателем для верификации краткосрочного прогноза на фоне консервативной терапии.

КЛЮЧЕВЫЕ СЛОВА: внутримозговое кровоизлияние; ферритин; прогноз.

\section{ANALYSIS OF INFORMATIVENESS OF SERUM FERRITIN CONCENTRATION IN DETERMINATION OF SPONTANEOUS SUPRATORIAL INTRACEREBRAL HAEMORRHAGE ACUTE PERIOD COURSE AND OUTCOME PROGNOSIS}

๑) A. A. Kuznietsov

\section{Zaporizhzhia State Medical University}

SUMMARY. The aim - to evaluate the informativeness of serum ferritin concentration in determination of individual risk of early clinical neurological deterioration and acute period outcome prognosis of spontaneous supratentorial intracerebral hemorrhage (SSICH) on the ground of conservative therapy.

Material and Methods. Prospective cohort comparative study of 88 patients in the acute period of SSIH on the ground of conservative treatment was performed. Neurological deficit evaluation was made by using Full Outline of Unresponsiveness scale and National Institute of Health Stroke Scale (NIHSS). Brain structures visualization was made by computed tomography. During $24 \mathrm{~h}$ hours from admission serum ferritin and iron levels, total iron-binding capacity and transferrin saturation ratio calculation was done. Early neurological deterioration (END) and unfavorable acute period SSICH outcome as grading 4-6 scores by modified Rankine scale on the 21st day of the disease were chosen as clinical combined end points. Statistical processing was performed with logistic regression analysis, ROC-analysis and correlation analysis.

Results. The patients with unfavorable variants of SSICH acute period course and outcome were characterized with higher serum ferritin level in the $1^{\text {st }}$ day from admission, thus that parameter was directly associated with brain structures injury severity. It was detected that evaluation of serum ferritin levels together with neurovisualization parameters (severity of midline shift, secondary intraventricular hemorrhage volume) as part of elaborated multipredictive logistic regression model gives the opportunity to predict END with high accuracy 89,8 \% (AUC \pm SE $[95 \% \mathrm{Cl}]=0,94 \pm 0,03$ $[0,86-0,98], p<0,0001)$. A highly sensitive multipredictive logistic regression model was also developed that incorporated prognostic value of serum ferritin concentration with clinical and neurovisualization parameters (NIHSS score, secondary intraventricular hemorrhage volume). It helps to identify individual risk of unfavorable acute period SSICH outcome on the ground of conservative management with accuracy 87,5\% (AUC \pm SE $[95 \% \mathrm{Cl}]=0,95 \pm 0,02[0,89-0,99], p<0,0001)$.

Conclusions. Serum ferritin concentration in patients with SSICH is an informative additional parameter for shortterm prognosis verification on the background of conservative therapy.

KEY WORDS: cerebral hemorrhage; ferritin; prognosis. 